\title{
Africa and the International Political Economy: Meeting the Challenges of the Global Economic Meltdown
}

\author{
Idahosa Osaretin, $\mathrm{PhD}$
}

Ukpebor Edith Ehiosuomwan Mary

Department of Political Science and Public Administration, University of Benin, Benin City, Nigeria e-mail: thechurchofbelievers@yahoo.com 08066400829,08037163838

Doi:10.5901/ajis.2013.v2n2p243

\begin{abstract}
This paper examines the impact of the global financial meltdown on African economies. Despite the initial optimism that the continent would be insulated from the crisis, there is a correlation between African economic performance, especially that of Sub-Saharan Africa, and the weakness in the global economy. This is especially reflected in the continent's trade relations with major economies of the world. Moreover, with Africa's development partners now forced to undergo more rapid local fiscal consolidation, African economic turfs are wary of the prospect of further cuts in foreign aid budgets. Thus, reductions in Official Development Assistance (ODA) are a threat to Africa's overall development strides. The paper traces the evolution of African economies in tandem with global political economy. It discovers that while the current global financial crisis provides fundamental lessons for Africa, economic planners in the continent should rise up to the occasion and explore new pathways to an endogenous development for and by the African people.
\end{abstract}

\section{Introduction}

Africa's place in the global economy is less central than that of any other region in the world. The international political economic structure provides the umbrella used by states to achieve development for their respective countries. The mileage which individual state attains cannot be extricated from the overall dynamics existing within contemporary international system. By the middle of the $20^{\text {th }}$ century, there emerged a number of newly independent African states making their entrance into the global market economy. Various theories were postulated for these infant states as development pathways. However, despite the preponderance of ideas and theories concerned with development, the level of progress achieved in these countries remained economically inferior to that of more advanced Western societies. Although, as Kuznets (1968:2) notes "we must be careful when making sweeping generalization as to what constitutes development seeing that the concept of development / underdevelopment is highly ambiguous and could mean several different things, depending on the perspective from which observation were made". This caveat notwithstanding, African countries continue to be economically and technologically dependent. They are commodity and raw materials exporting economies, importing manufactured and finished goods in return.

Apart from a few African countries which experimented the Marxian models of economic development (principally aided by Cold War concerns), others domesticated the liberal economies policies. Rather than achieving upward mobility in the stages of economic development as was initially anticipated, the application of these development models left African countries with stunted development as their economies were mired in slow growth (Gilpin, 1987). The failure to secure development through the above stated policy prescriptions necessitated a rethinking on more viable strategies for sustainable development.

However, the current global financial crisis poses a lot of developmental challenges to the continent. Since it started in the middle of 2007, stock markets around the world have fallen, large financial institutions have collapsed or been bought out, and governments in, even the wealthiest nations have had to come up with reserve packages to bail out their financial systems. Due to Africa's underdeveloped financial markets, the continent's economy remains largely threatened by the financial problems experienced in the United States, Europe and other parts of the world. On the other 
hand, the global financial meltdown is beginning to affect the livelihood of almost everyone on the continent in an increasingly inter-connected world.

This paper is an attempt to identify the place of Africa in the global economy. The current global financial meltdown is its veritable turf. The paper starts with an introductory note closely followed by theoretical perspectives on the fundamental issues of the discourse. The impact of the aforesaid and possible pathways to surmount the challenges for the continent concludes it.

\section{Theoretical Perspective}

In the context of this discourse, the World Systems Approach would be apt. This theory sees the global community as a unit with single division of labour and multiple cultural systems. Thus, Wallerstein (1999), describes the international system as one characterized by mechanisms which bring about a redistribution of resources from the periphery to the core. Impliedly, the core is the developed, industrialized, democratic part of the world which economically exploits the poor, raw materials - exporting, less developed countries - the periphery, through the means of the market. As such, nation - states are all part of the world system of capitalism. According to Wallerstein (1999:1):

the modern nation - state exists within a broad economic, political and legal framework which he calls a "world system" just as individuals' behaviours cannot be understood without reference to socio - cultural system in which they are members, societies or nation - states cannot be understood without reference to the world - system in which they are embedded.

From the small, homogenous societies, through the "world - empire", to the world economies, capitalism is the underlining denominator. In this regard, international capitalism is the mechanism of surplus appropriation; both subtle and efficient. It relies on the creation of surplus through constantly expanding productivity. Also, the capitalist world system is based on a two - fold division of labour in which different classes and status groups are given differential access to resources within nation - states; and on the world market. Both types of markets, within and amongst nation states are very much distorted by power.

Nonetheless, it is the economic, political and military power of the core that allows significant capital to be accumulated in the hands of the few. In essence, it is the capitalist world - system that produces and maintains the gross economic and political inequalities within and between nations. As with capitalism, within nation-states, this unequal power between / amongst nation-states is not uncontested. It is a subject of struggle. These are internal contradictions, that with the passage of time, cause political and economic instability and social unrest. Eventually, according to Wallerstein (1999), a world - wide economic crisis will be reached and the capitalist world - system will collapse, opening the way for revolutionary change.

The current international financial crisis points to the collapse of the capitalist world - system and discredits market fundamentalism. Africa has not escaped the crisis unscathed. Falling demand internationally has dampened African exports. Tightening trade flows have also posed a problem for many of the continent's countries. More pressingly, the crisis has strained international aid organizations, limiting their ability to provide humanitarian relief to some of the continent's poorest countries. On the one hand, most Africans are concerned that those responsible for the financial problems are the ones being bailed out, while on the other hand, the global financial meltdown affects the livelihoods of almost every African.

\section{African Economies in the Global Context}

The 1960s marked a watershed in modern Africa, as most African countries became independent in this era. By 1964, the report "Towards a New Trade Policy for Development" was published; arguing that the world economy was biased against the development efforts of African countries. In the United Nations Conference on Trade and Development (UNCTAD) session of the same year the earliest foundations for the demand of the Less Developed Countries (LCDs) for a New International Economic Order (NIEO) were laid (Adams, 1985). With arguments presented by Raul Preblisch and Hans Singer, the composition of the international economic system was questioned. Simply put, their premise was stated thus: 
the nature of technical advance, cyclical price movements, and differences in demand for industrial goods and primary products cause a secular determination in terms of trade for commodity exporters, that is deterioration of the prices the LDCs receive for their commodity exports relative to the prices of manufactured goods they import from developed countries (Gilpin, 1987: 275).

Similar views held by the mainstream structuralist school of thought called for a new order in the international system that would guarantee the ability of African states to achieve economic development. This was more so as the failure of alternative strategies such as import substitution, self - reliance and economic regionalism to achieve development raised the form of action plan to engender development in the continent.

After the Charter of Economic Rights and Duties was adopted by the UN General Assembly on December 14 1974, there was palpable belief that industrialization and economic development of Africa was indeed possible if institutional reforms were undertaken. However, the NIEO (despite its laudable ideas) failed due to a number of reasons. These included the hesitance of the More Developed Countries (MDCs) to make significant concessions; the low level of cooperation among African countries (partly due to colonial heritage); and the oil boom that proved beneficial to oil exporting African states and near disastrous outcomes to the non - oil exporting ones (Adams, 1985).

Aside the NIEO, the international economy had been entrenched on the Bretton Woods system since the end of the Second World War. Its institutions include the International Monetary Fund (IMF), World Bank and the General Agreements on Trade and Tariffs (GATT) (later transformed into the World Trade Organization). Their collective activities determine, to a large extent, the terms of international trade, exchange and development, either at the unilateral, bilateral or multi - lateral levels. Suffice to say that the decision - making roles and functions of these international organizations are pliant to the course of global economic and political powers. Obviously, Africa's interest is not at the driving seat of these organizations. Particularly with the IMF, it is a story of unsustainable loan deals that have led to the highly indebted status of most of the countries in the region. While it may be argued that the trade rounds of the GATT through the WTO have been of great benefits to some countries (e.g. South Africa, Egypt, Morocco, Nigeria etc), poorer African countries have always struggled hard to gain a foothold in growth and development through agriculture and other sectors of their economies as they face barriers placed by the very countries most promoting the benefits of trade openness (Todaro and Smith, 2009; Gum, 2009).

While the MDCs tended to promote trade and economic policies that could provide advantages and opportunities for African countries, they employed double standards in practical terms in their relations with the region. For example, as the United States promoted the Africa Growth and Opportunities Act (AGOA), and continental Europe promoted the European Partnership Agreement (EPA), their contradictory economic policies and actions in the WTO enhanced trade protectionism. These affected poor African countries that were forced to compete in the same world market. The inconsistencies of such policies and actions were observed with the agriculture, agro-allied and manufacturing industries. Thus, African countries are unable to compete in the global market.

Furthermore, for most of the 1980s, 1990s and well into the 21 st century, the Washington Consensus which reflected the pro-capitalist free market approach to economic development held sway. A noticeable contradiction was the dual application of its principles to countries (Couier, 2007). East Asia favoured by the US and the European allies on the one hand, and African and Latin American countries on the other. These countries were pressured to comply with the ten - point agenda of the consensus: tax reform, unified and competitive exchange rates, deregulation, trade liberalization, elimination of barriers to the free - flow of international fiscal relations, and financial liberalization among others. These policies led to the introduction of the Structural Adjustment Programme (SAP) in most African countries. As such, African countries were further impoverished. The absence of mutual growth, de-emphasis on poverty elimination, and reduction of inequality gave rise to a situation where the above mentioned policy prescriptions had minimal effects.

However, with the tacit support of the drivers of these policies, few African countries (Uganda, Ghana, etc) were able to take advantage of the international economic and fiscal regime to experience marginal growth. Even at that, the growth was not in terms of real Gross Domestic Product (GDP), given that these countries were primary commodities exporters. This possibly explains why the approach was later considered inadequate, even by the proponents of the consensus.

\section{International Political Economy and the Global Financial Crisis}

The chronology of global development since the turn of the $21^{\text {st }}$ century has been replete with significant consequences 
that have, in more ways than one, affected either positively or negatively the over 7 billion people living in the world today. Globally, the structure of the International Political Economy (IPE) has created a situation where events in one part of the globe have correlating effects in other parts. Fuelled by the growth of information and communication technology, the de - facto fusion of international finance and the presumed ascendancy of the capitalist economic ideology over communism and nationalism, the globalization of the human community has been accelerated in no small measure. Nonetheless, globalization has more or less rendered national boundaries seamless, which in essence, has shrunk the world both in time and space. This created the possibility of the consequences of economic and political policies spilling across national boundaries and affecting countries not contiguously located.

The above is often given expression in terms of Foreign Direct Investment (FDI) - the presence of foreign investments in the economies of host countries. The general opinion that foreign capital plays an important role in the economic growth of developing countries is a corollary of the view that no one developing country can attain development without the aid of external capital (Jhinghan, 2007). However, while FDI might prove erratic, the dependence of most African economies on foreign aids and grants has grown over the years, especially as a result of their seeming contribution to the achievability of the Millennium Development Goals (MDGs). According to lyoha:

\section{there is now a consensus that the MDGs will not be achieved without massive and substantial assistance from the rich countries. Unfortunately, up till now, the response from the rich countries has been feeble and has fallen far short of the requirement (lyoha, 2005:16).}

In line with the necessity for foreign capital inflow into the domestic economies of African states is the remittances provided by nationals working in the Diaspora. African Diaspora has contributed immensely to the development of the continent. Since the turn of the century, a conservative estimate of what accrues to the continent annually via remittance stands at about $\$ 50$ billion. Thus, the economic impact of remittances has been considered beneficial at both the micro and macro levels. The value of migrant remittance can significantly exceed that of natural export earnings. For example, Eritrea receives about 40 percent of her GDP through remittance, whereas exports contribute about 4 percent of the GDP (Rena, 2010). However, this means of deriving foreign capital unfortunately experienced a slow down due to the global financial meltdown of 2008.

With millions suffering pay cuts and job layoffs, the result was a mass exodus of African returning back home. For example, at its height, it was reported that over 10,000 Nigerians returned to the country on a monthly basis (Dapline, 2009). The impact of the meltdown, aside from the drop in remittances is still being felt all over Africa where commodity exports suffered severe price shocks.

In Nigeria the banking industry which hitherto was perceived as the backbone of the economy due to the consolidation exercises prior to the meltdown, still reels from the shock that came in the wake of the crisis. It also reverberates in the equity market which is directly exposed to the flux and fluctuation of the world economy. Also the Nigeria Stock Exchange experienced over a $60 \%$ fall in price index due to the mopping up of foreign capital by portfolio investors (The Nation, 2009). The unfortunate outcome is the deterioration of an almost non-existent manufacturing sector that is far from being revived, a declining productivity level and spiraling unemployment. Besides, the slowdown of FDI and dwindling remittances, there are far more fundamental challenges facing African countries as the crisis is far from over (Stiglitz, 2009).

The rhetoric hierarchy since the economic bubble burst in the last quarter of 2008 has been one of change. To this effect, restructuring, increased government intervention and regulation, accountability and a more decentralized capitalist system, (where the market though free, maintains some elements of institutionalized regulations) were recommended. Also, issues of nationalism and protectionist policies are increasingly becoming common place in the US and Europe even as most of new protectionist measures, most notably the US with the "buy American" provision included in her multi - billion dollar stimulus package to her ailing industries in particular and economy in general (Stiglitz, 2009).

The extent to when these new ways of doing things will go, if at all, should be juxtaposed with the ability of the world economy to jettison the obviously unsuitable capitalist consumerism on which the contemporary order is premised upon. The promotion of international capitalism based on the principles of Washington Consensus, entrenched through globalization is largely responsible for the current morass of the world economy.

Obviously, the interest of the African continent is outside the core policy objective of the IMF, WB and WTO. The ambivalence of the international political economy coupled with protracted leadership problem in the region principally explains the underdevelopment of the continent. In an international system where rules are selectively applied, and 
economic brigandage and permissiveness exists, where double standards saturate the relationships that exist between and among states, there is a Herculean challenge for countries, especially African countries to rise up to the occasion.

Under such an environment, the challenge which African economies face is not to be overly dependant on international assistance (be it in form of aids/grants or foreign direct investment) but to increase the productivity level of domestic economy. According to the late Nigerian President Yar' Adua;

if our Vision $20-20-20$ is to be realized, and sustained, improved productivity will have to be taken seriously and accepted as one of its cardinal pillars --- meeting the Millennium Development Goals can only come about if we individually and collectively embrace the productivity culture in its entirely (Fanimo and Olayinka, 2009: 39).

Furthermore, one cannot talk about productivity in the absence of a strong industrial base. In this regard, the prostrate nature of infrastructure in Africa and the failure of African governments to channel the continent's resources into development enhancing activities underline the problem. It must be emphasized that for sustained growth and development to occur, the state apparatus has got a lot of roles to play. Only government assisted by vibrant public sectors that are development oriented can hope of achieving any meaningful mileage in their quest for development irrespective of the dynamics of the international political economy.

\section{Effects on African Economies}

Despite the initial optimism that the global financial crisis might not cross the African border, headwinds associated with continuing global uncertainty persists. The continent has not been immune to the slowdown. With intra - regional trade estimated to account for as little as $10 \%$ of total trade (poor infrastructure is largely to blame), Africa's export growth remains highly correlated with world growth (Nigerian Compass, 2010). As the financial crisis continues to ravage the Western nations, it can be expected that foreign investments in Africa will reduce as the resultant squeeze takes hold, in the long run.

Also, foreign aid, which is important to a number of African countries, is likely to diminish. These countries could face increasing pressure for debt payments. As the crisis gets deeper and the international institutions and Western banks that have lent money to Africa need to shore up their reserves more; one way could be to demand debt repayment. This could cause further cuts in social services such as health and education, which have already been reduced due to crises and policies from previous eras. Much of the debts owed by African nations are odious or unjust debts, which would make any more aggressive demands of repayment all the same worrisome. Some African countries have already started to cut their health and HIVIAIDS budgets due to the economic crisis. Their health budgets and resources have been constrained for many years already, so this crisis makes a bad situation worse. According to International Political Survey (IPS) reports (cited in Shah, 2010: 18), "already, large percentages of households in Sub - Saharan Africa are poor, and the large number of people on treatment means ever - increasing programme costs".

It is instructive to note that prior to the global financial crisis, African economies, unlike the more established ones in other regions of the world had been largely insulated from global contagion when risk aversion peaked. This has now changed. Recent economic crisis in Europe (starting with Greece and now Ireland) has made its mark on smaller African economies as well, with most African currencies weakening in response. Regardless of the fact that the continent's trade with Europe is dominated by the core economies rather than the peripheral ones, the market reaction reflects the view that Africa will be negatively impacted by any renewed downturn in euro-zone growth prospects.

The above scenario would be the case, especially if other developing regions, with which Africa's trade is increasing, were to slow as well - with a knock-on impact in commodity prices. A further deterioration in global risk appetite may negatively impact the cost of borrowing for the continent. Because Africa's development partners are now forced to undergo more rapid fiscal consolidation, markets in the continent are wary of the prospect of further cuts in foreign aid budgets. The recent round of East African budgets in June 2010 already showed signs of reduced donor support to Tanzania and Uganda, although in both cases, the causes have more to do with the pace of reform in recipient economies than fiscal rebalancing in donor countries (Nigerian Compass, 2010). Thus, reductions in Official Development Assistance (ODA) are a threat to Africa's economic fortunes.

Sequel to the forgoing, the current global financial crisis provides fundamental lessons for Africa. Apart form breaking the myth of the sanctity of market - self - correcting mechanisms, it has also shown that market failures are not less costly than state failures. As such, 
the collapse of the neo-liberal dogma is a major blow to the international financial institutions. What is even more devastating to them is the reversal of most of the policies they had advocated for decades in Africa and in other 'poor' countries under the now discredited Structural Adjustment Programme (SAP) (Dembele, 2010).

In essence, it is clear that the state remains a central player in solving crises caused by markets, and is not the sole cause of economic and social problems in Africa that neo-liberal policy has categorized it as. Therefore, African economic planners should rise up to the occasion and explore new pathways to 'an endogenous development for and by it people'. To guarantee this, African governments should restore the role of the state in the development process of the continent; while at the same time learn from the experiences of other countries in the global South. This is needful to build an alternative means for financial development, including South-South cooperation and the integration of Diaspora remittances into a coherent strategy.

\section{Conclusion}

The impacts of the global financial crisis have been pervasive. In spite of initial optimism, African economies are beginning to bear the weight of the downward global economic spiral. This paper has examined the place of Africa in the international global economy with special reference to effects of the current economic glut on domestic economies on the continent. It believes that, given the magnitude of the crisis, African states should have the courage and political will to break with failed and discredited neo-liberal dogmas. This, in a nutshell, would enable the continent to chart its own development and take responsibility for it.

\section{References}

Adams, J. (1985) The Contemporary International Economy. New York, St. Martins Press

Couier, P. (2007) The Bottom Billion: Why the Poorest Countries are Failing and What can be done about it. New York, Oxford University Press

Dembele, D. M. (2010) "The Global Financial Crisis: Lessons and Responses from Africa". Available at http://www.pambazuka.org/en/category/features/54982, accessed 2/12/2010

Fanimo, D. and Olayinka, C. (2009) "Pushing the Frontiers of Productivity for National Development". The Guardian, July 7

Gilpm, R. (1987) The Political Economy of International Relations. New Jersey, Princeton University Press

Gum, D. (2008) "New Flare Out Date Unacceptable, ERA", Vanguard October 13

Iyoha, M. (2005) "Financing Africa's Development: A Global Imperative in the 21st Century". Paper Presented at the Workshop on National Awareness on UN Reforms, Organized by the Presidency in Collaboration with the Faculty of Social Sciences, University of Benin, Benin City, Nigeria

Jhingham, M.I. (2007) The Economies of Development and Planning, 39th Edition, New Delhi, Vrinda

Kuznets, S. (1968) Towards a Theory of Economic Growth. New York, W. W. Norton

Nigerian Compass, (2010) Sub-Saharan African: High Expectation of Economic Growth, Tuesday December 31

Rena, R. (2010) "Brain Drain and Brain Gain in Africa". Available at http://www.africaeconomicanalysis.org/articles/gen/brain_drain.html, accessed 02/12/2010

Todaro, M. P. and Smith, S. C. (2009) "Economic Developments Esset", Pearson Education

Shah, A. (2010) Global Financial Crisis. Available at http://www.globalissues.org/article/768/global-financial-crisis, accessed 2/12/2010

Stiglitz, J. (2009) "Developing Countries and the Global Crisis". Business Day, April 16

The Nation (2009) "The Nigerian Stock Exchange Report, Thursday May 21

Wallerstein, I. (1999) The End of the World as We know it. Minnesota, The University of Minnesota Press

Young, V. A. (2009) "Labour Lament Factory Closures, Job Losses". Vanguard April 23 